\title{
Problems of Microcredit among Microenterprises in Nigeria
}

\author{
JOHN N. N UGOANI, Ph.D* ONWUBIKO N. DIKE, MBA \\ Department of Management Sciences, Rhema University, P.M.B. 7021 Aba, Abia State, Nigeria \\ * E-mail of the corresponding author: drjohnugoani@yahoo.com
}

\begin{abstract}
This study was designed to assess the problems of microcredit among microenterprises in Nigeria and make recommendations for remedial strategies. Microcredit refers to small loans made available to small producers otherwise known as the active poor to enable them start new productive activities, grow or sustain existing ones. The study was delimited to Aba which has the highest concentration of microenterprises in the South East Zone of Nigeria. The survey research design was used, and the questionnaire and face-to-face interview methods were used for data collection. Data were analyzed using tables, frequencies, percentages and Z-test statistics. It was found that problems of microcredit have significant effects on the performance of microenterprises in Nigeria. Ten recommendations were made based on the findings of this study.

Keywords: Microcredit, Microenterprises, Micro-entrepreneurs, UNDP, MfB, CBN, Peru, Soft loans, FEAP, MSMEs, Vulcanizers, Venture Capitalist .
\end{abstract}

\section{Background:}

Microcredit typically refers to the provision of financial or banking services, primarily to petty businesses known as microenterprises that do not have access to formal financial institutions. Conventional banks perceive microenterprises as bad risk hence they pay less attention to their credit requests. In realization of the fact that an enduring economic advancement may not be achieved without working out well articulated poverty reduction agenda through empowering the people, increasing their access to credit, the Federal Government of Nigeria launched the Peoples Bank Programme in 1989, followed by Community Banking Project in 1993. Other such moves aimed at providing micro credit included the Family Economic Advancement Programme (FEAP) among others. Another unique attempt at providing microcredit was made in 2004 by the Central Bank of Nigeria (CBN) with the launching of the Microfinance Bank (MfB) Programme with the specific objective of making microcredit easily available to those who were traditionally denied access to banking credit. Credits come in different sizes. Some come in billions, millions and many thousands, while the requirement of others run into a few thousands and hundreds. Microcredit has to do with soft loans granted to small producers and enterprises to enable them produce or improve their productive activities. It includes loans of N10,000.00 - N100,000.00 etc given to such entrepreneurs as hair dressers, barbers, vulcanizers, auto mechanics and auto electricians, welders, petty traders, palm producers, small farmers among others. Generally speaking, there is no upper limit ceiling of what constitutes a microcredit, but the focus of microcredit is the satisfaction of the needs of many small producers otherwise known as the active poor (Nzenwa, 2000). Because of the importance of microcredit the Nigerian Government is actively collaborating with International donor agencies such as the United Nations Development Programme (UNDP) in providing microcredit to microenterprises in Nigeria. (NBCS, 1993, CBN, 1994). Microcredit has become a global phenomenon as many countries have embraced it towards promoting National Economic Development. For example a country like Peru has focused on microenterprises for national economic progress. It defines microcredit as loans granted to microenterprises with volumes of assets excluding fixed assets below US $\$ 20,000.00$ and accumulated debt below US $\$ 20,000.00$. Also, in Colombia, microcredits are loans granted to microenterprises with fewer than 10 employees and total assets below 501 times monthly minimum wages or US $\$ 115.60$ per month. In the Philippines, microfinance loans refer to small loans granted to poor and low income households for their microenterprises and small businesses. The maximum amount of a micro loan is approximately 150,000 pesos or US $\$ 2,700.00$. These few examples were used to buttress the importance of microcredit and microenterprises at the macro level (Ledgerwood White, 2006). The challenges among microenterprises in Nigeria today indicate that they find it very difficult if not impossible, to have access to microcredit both from the conventional banks and even the microfinance banks setup for the purpose. To reverse the situation many Nigerians are questioning the roles of the banks in this respect. Research shows that a significant percentage of microcredit to the informal or private sector goes to the other private sectors such as salary/wage earners other than micro, small and medium enterprises (MSMEs). Private sector businesses without governmental control are composed of largely of micro, small, and medium enterprises, individuals and households. Obviously a high proportion of this sector consists of households and the unique characteristics of households in every economic system is consumption. Therefore, these households exchange money for goods 
and services provided by business enterprises, and since most MSMEs do not possess necessary collaterals to meet lending requirements in Nigeria, a large proportion of microcredit to the private sector goes to households who are frequently salary earners and again whose primary reason for microcredit facility is consumption and not for productive activities. Apathy, repayment issues, low literacy, ill record keeping ineffective communication inadequate capacity building, lack of group identity, are among the problems of microcredit that are capable of having effects on microenterprises.

1.1 Statement of the Problem:

The challenge persists to the extent that microenterprises have little or no access to finance due to lack of banking relationship, account books, acceptable security, information, etc. Among the major challenges facing Micro, Small and Medium Enterprises (MSMEs) is high interest rate. And to provide some remedial actions, the First Bank of Nigeria Plc, recently signed a Memorandum of Understanding (MoU) with the Nigeria Association of Small Scale Industrialists (NASSI) that could enable the banks give loans to MSMEs at a single digit rate. According to the Bank, the MoU is in furtherance of the banks support for MSMEs and meant to promote the growth and development of the sector. The MoU also supports the bank's strategic focus on financial inclusion policy as it would mitigate the challenges of credit delivery to the unbanked market's segment through mobilized funds that will avail credit facilities to registered NASSI members at concessionary rate. Also the Central Bank of Nigeria (CBN) has established Entrepreneurship Development Centers (EDCs) to build capacity of MSMEs as well as curb youth unemployement. (Eshanokpe, Onasanya, 2012). For example, according to Gills - Harry (2012) Banks are killing businesses. According to him, "Banks of course are still very slow in supporting businesses, Nigerian banks only know how to keep money and charge high transaction costs. This is discouraging. Business concerns and CEOs are groaning under these very harsh and painful economic conditions. Funds to expand and situate existing projects are hard to come by. Banks are not forthcoming in spite of high profit declared. We need to investigate where these banks operate in or from". Informed statements like this give a very clear indication that microenterprises in Nigeria have serious problems of microcredit. For example, only $\mathrm{N} 8.5$ billion (29.5\%) of $\mathrm{N} 28.8$ billion meant for microenterprises was utilized as at 2004. Also CBN report showed that out of community banks deposit of N21.4 billion their loans to microenterprises as at December, 2004 were only N11.4 billion (Akinboyo, 2007). But banks cannot usually lend without the problems of microcredits being explained, and this is compounded by the dearth of venture capitalists in Nigeria. For example, to create window for microcredit, for microenterprises, the Federal Government of Nigeria (FGN) believes that the paradigm shift to microfinance is imperative because it will enable households to have access to other financial services distinct from microcredit for microenterprises. While the terms "microcredit" and "microfinance" are often used interchangeably they have different connotations and are loosely attached to contrasting beliefs. Like other people, the active poor needs access to a wide range of financial services that are convenient, flexible, and reasonably priced. Just like the rich, the active poor needs microloans to invest in businesses, to meet personal needs, and to sail through cashflow crises. (NDIC,2011)

\subsection{Hypotheses:}

To guide the study, these hypotheses were formulated and tested at 0.05 level of significance.

$\mathrm{H}_{\mathrm{O}}$ : Problems of microcredit have no significant effects on the performance of microenterprises in Nigeria.

$\mathrm{H}_{\mathrm{I}} \quad$ Problems of microcredit have significant effects on the performance of microenterprises in Nigeria.

1.3 Delimitation of Study

This study was designed to assess the effects of the problems of microcredit on the performance of microenterprises. Three Local Government Areas within Aba metropolis, namely, Aba South, Aba North and Osisioma were selected for the study due to the high consentration of microenterprises in the areas. The uncooperative attitudes of the respondents, dearth of information and poor road networks in the areas posed serious limitations, but never dimished the quality of the study.

\section{Literature Review}

The ability to source capital is a fundamental component for a micro-enterprise to grow. Young entrepreneurs in Nigeria need to apply and get approval for startup loans at the local Branch of a commercial bank before they can transform their ideas into reality. Most of these people are poor and located in rural areas, run small-scale businesses with few assets, and use mainly family members for labour supply, paid staff are very few. Obtaining startup finance is not always easy or simple, even for successful entrepreneurs. Business loan applications can be difficult, often requiring detailed financial projections and business plans. Some banks require proof of employment, letters of reference or other documents for the purpose of establishing account relationship, all these lead to setbacks and frustration for microenterprises. The reality is that new entrepreneurs and microfirms typically lack the competence to prepare detailed business plans. In Nigeria professional consultants are hired to 
prepare such documents that are required as part of loan applications. The fees charged by these consultants can be as much as 1 to 5 percent of the loan request amount, and if required to be paid up front, the entrepreneur who has no money would have no choice than to wait. In Nigeria, loan terms are short and inflexible, making it challenging to borrow for lager, longer term projects. For example, the usual term available for microenterprises is one year. Collateral requirements can present a serious obstacle. Some banks insist on accepting only completed houses or buildings with statutory certificates of occupancy as collateral, but many entrepreneurs do not possess such documents, at best some can only boast of customary Right of Occupancy, which is however not acceptable by banks for loan approval. In a few cases, where buildings are offered and accepted as collateral, entrepreneurs are unable to leverage such assets to obtain additional business capitals. Complex documentations by commercial banks screen out potential entrepreneurs who may be deterred by unnecessary and difficult requirements. Often, this high complexity is associated with lower levels of use of the banking system and lower levels of microcredit. The efficiency of application processing is vital for microfirms but this is adversely affected because banks usually spend more time in evaluating fresh requests. In this country commercial banks take up to three weeks to review a loan request and in some extreme cases, the applicants do not even receive a response at all. Ratios of collateral to loan values are very high in Nigeria, and it can range from $120-150$ percent. In the case of cash collateral, banks generally demand for 100 percent cash cover before loan approvals. Banks however base their insistance on high security values on the high rate of default, in the Nigerian banking system, and again they do not readily accept assets such as equipment, accounts receivable, and inventory to secure loans because of depreciation in value of such assets. The lending environment is an important factor in increasing access to credit for microenterprises. Issues of functional credit information system, and a competitive banking sector do not exist to enhance entrepreneurs chances of accessing microcredit. The overall picture is one of penniless entrepreneurs ${ }_{1}$ small in scale, unskilled, and with little capital. The enterprising poor people are hobbled by a lack of credit. Banks will not lend to them because they have few assets to post as security and because banks find it expensive to screen and monitor small-scale borrowers. In response to the dearth of credit to microenterprises, microfinance programmes have taken off in developing countries over the past decades. Majority of the Nigerian rural active poor still do not have access to banking facilities. Worse still microenterprises are disappearing due to lack of credit. A 2009 World Bank Report showed that in Nigeria the number of accounts per thousand adults was 185; and the number of accounts per thousand inhabitants was 103. The same report showed the figures for Philippines thus: number of accounts per thousand adults 566, and the number of accounts per thousand inhabitants 363. (Ashraf, Nava, Dean Karlan, and Wesley Yin, 2006a) When these figures are compared it would become manifest that Nigerian rural active poor has little or no access to banking facilities. Because of the lukewarm attitude of the conventional banks in addressing the needs of microenterprises the Central Bank of Nigeria embarked on the development of the microcredit initiatives, in tandem with the global trend. (Akinboyo, 2007, Bazoberry, Eduardo, 2003, Bruett, Till, 2005, Campion, Anita, and Victoria White, 1999, Campion, Anita, Elizabeth Dunn, and J. Gordon Arbucke Jr, 2002, Charitinenko Stephaine, 2003, Banking the Poor, 1999, Moses-Ashike, 2012). It is not a credit to swallow the argument that the active poor do not have significant access to education. They can take the best available opportunity to enhance their knowledge particularly now that the National Universities Commission (2011) has made entrepreneurship education compulsory in all Nigerian Universities.

\section{Methodology}

This study employed the survey research design. The population of study, 1600 microenterprises, was drawn from the membership registers of the market associations/unions (table 1). These micro entrepreneurs classified as the active poor by the microfinance banks, viz, hair dressers/barbers, vulcanizers, petty traders, welders, tailors (Seamstress), shoe makers (Cobblers) and food vendors were chosen on the basis of their preponderance in the areas. A sample size of 320 respondents was derived, using Yamane's (1967) formula. The sample size of each stratum was determined by the use of Bowley's proportional allocation statistical technique (Table 2). The questionnaire was designed in a five point likert scale format and tested for both construct and content validity. In-depth face-to-face interviews were held with both the officials of the microfinance banks and the executive/members of the respective market associations/unions in Aba metropolis. A pilot study, involving 70 microenterprises was conducted and the data analyzed using Cronbach's Alpha technique to determine the reliability of the research instrument. A reliability coefficient of 0.92 was estimated, indicating high internal consistency of the research instrument. The Z-test statistical technique was applied in testing the hypotheses of the study. 
4. Data Presentation And Analyses.

Table 1: Population distribution of Microenterprises in Aba Metropolis

\begin{tabular}{|c|c|c|c|c|c|c|c|c|}
\hline $\begin{array}{l}\text { Areas of } \\
\text { Study }\end{array}$ & $\begin{array}{l}\text { Hair } \\
\text { dressing } \\
\& \\
\text { Barbing }\end{array}$ & Vulcanizing & $\begin{array}{l}\text { Petty } \\
\text { trading }\end{array}$ & Welding & $\begin{array}{l}\text { Tailoring } \\
\text { (seamstress) }\end{array}$ & $\begin{array}{l}\text { Show } \\
\text { making } \\
\text { (Cobblers) }\end{array}$ & $\begin{array}{l}\text { Food } \\
\text { vendors }\end{array}$ & Total \\
\hline $\begin{array}{l}\text { Aba } \\
\text { South }\end{array}$ & 80 & 35 & 150 & 30 & 55 & 70 & 200 & 620 \\
\hline $\begin{array}{l}\text { Aba } \\
\text { North }\end{array}$ & 60 & 30 & 125 & 25 & 50 & 100 & 190 & 580 \\
\hline Osisioma & 35 & 20 & 90 & 15 & 30 & 60 & 150 & 400 \\
\hline Total & 175 & 85 & 365 & 70 & 135 & 230 & 540 & 1,600 \\
\hline
\end{tabular}

Source: Field survey, 2013

Table 1 showed the study population of 1,600 microenterprises registered with their respective market associations/unions in Aba metropolis.

Table 2: Sample size of microenterprises in Aba Metropolis

\begin{tabular}{|c|c|c|c|c|c|c|c|c|}
\hline $\begin{array}{l}\text { Areas of } \\
\text { Study }\end{array}$ & $\begin{array}{l}\text { Hair } \\
\text { dressing } \\
\text { \& } \\
\text { Barbing }\end{array}$ & Vulcanizing & $\begin{array}{l}\text { Petty } \\
\text { trading }\end{array}$ & Welding & $\begin{array}{l}\text { Tailoring } \\
\text { (seamstress) }\end{array}$ & $\begin{array}{l}\text { Show } \\
\text { making } \\
\text { (Cobblers) }\end{array}$ & $\begin{array}{l}\text { Food } \\
\text { vendors }\end{array}$ & Total \\
\hline $\begin{array}{l}\text { Aba } \\
\text { South }\end{array}$ & 16 & 7 & 30 & 6 & 11 & 14 & 40 & 124 \\
\hline $\begin{array}{l}\text { Aba } \\
\text { North }\end{array}$ & 12 & 6 & 25 & 5 & 10 & 20 & 38 & 116 \\
\hline Osisioma & 7 & 4 & 18 & 3 & 6 & 12 & 30 & 80 \\
\hline Total & 35 & 17 & 73 & 14 & 27 & 46 & 108 & 320 \\
\hline
\end{tabular}

Source: Field Survey, 2013.

Table 2 was derived from the population distribution of the registered microenterprises in Aba metropolis (Table 1). The stratified, simple random and convenience sampling procedures were adopted to select the 320 respondents who were served the questionnaire copies. For the illiterate microenterprises, the questions were interpreted for them and the responses filled in. The return rate of the questionnaire copies was hundred percent.

Table 3: Literacy levels of the microenterprises (respondents)

\begin{tabular}{|c|c|c|c|c|c|c|c|c|c|}
\hline $\begin{array}{l}\text { Qualificatio } \\
\text { ns }\end{array}$ & $\begin{array}{l}\text { Hair } \\
\text { dressin } \\
\text { g \& \& } \\
\text { Barbin } \\
\text { g }\end{array}$ & $\begin{array}{l}\text { Vulcanizi } \\
\text { ng }\end{array}$ & $\begin{array}{l}\text { Petty } \\
\text { tradin } \\
\text { g }\end{array}$ & $\begin{array}{l}\text { Weldin } \\
\text { g }\end{array}$ & $\begin{array}{l}\text { Tailoring } \\
\text { (seamstres } \\
\text { s) }\end{array}$ & $\begin{array}{l}\text { Show } \\
\text { making } \\
\text { (Cobbler } \\
\text { s) }\end{array}$ & $\begin{array}{l}\text { Food } \\
\text { vendor } \\
\text { S }\end{array}$ & $\begin{array}{l}\text { Tota } \\
\text { l }\end{array}$ & $\%$ \\
\hline FSLC & 12 & 5 & 16 & 4 & 7 & 13 & 75 & 132 & 41.25 \\
\hline $\begin{array}{l}\text { GCE/ } \\
\text { WASC/ SSC }\end{array}$ & 18 & 10 & 24 & 8 & 12 & 16 & 20 & 108 & 33.75 \\
\hline OND/NCE & - & - & 18 & - & 5 & 10 & - & 33 & 10.31 \\
\hline None & 5 & 2 & 15 & 2 & 3 & 7 & 13 & 47 & 14.69 \\
\hline Total & 35 & 17 & 73 & 14 & 27 & 46 & 108 & 320 & $\begin{array}{l}100.0 \\
0\end{array}$ \\
\hline
\end{tabular}

Source: Field Survey, 2013

Table 3 showed the literacy levels of the microentrepreneurs (active poor) selected for the study. The microenterprises were delineated by First School Leaving Certificate (FSLC) holders (41.25\%), followed by the holders of West African School Certificate (WASC) or its equivalent (33.75\%), and 14.69 percent of the respondents had no formal education. The microenterprises like petty trading, tailoring and shoe making attracted 10.31 percent of Ordinary National Diploma Certificate holders and its equivalents. 


\begin{tabular}{|c|c|c|c|c|c|c|c|c|c|c|}
\hline $\mathrm{S} / \mathrm{N}$ & $\begin{array}{l}\text { Problems of } \\
\text { Microcredit }\end{array}$ & 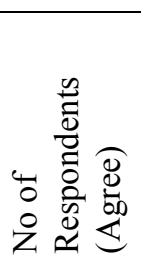 & 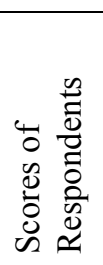 & 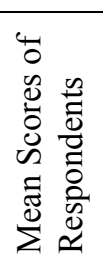 & 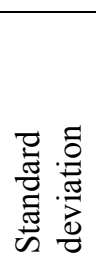 & 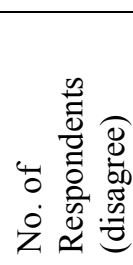 & 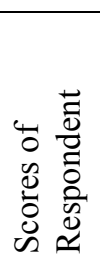 & 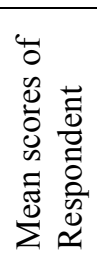 & 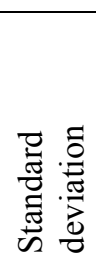 & 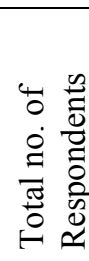 \\
\hline 1 & $\begin{array}{lll}\begin{array}{l}\text { Apathy of } \\
\text { entrepreneurs }\end{array} & \text { micro } \\
\end{array}$ & 180 & 810 & 4.50 & 2.62 & 140 & 280 & 2.00 & 1.36 & 320 \\
\hline 2 & $\begin{array}{ll}\begin{array}{l}\text { Loan } \\
\text { schedules }\end{array} & \text { repayment } \\
\end{array}$ & 210 & 840 & 4.00 & 0.35 & 110 & 273 & 2.50 & 2.01 & 320 \\
\hline 3 & $\begin{array}{l}\text { Illiteracy of micro } \\
\text { entrepreneurs }\end{array}$ & 200 & 900 & 4.50 & 3.90 & 120 & 314 & 2.60 & 1.47 & 320 \\
\hline 4 & Poor - record keeping & 200 & 850 & 4.25 & 0.35 & 120 & 240 & 2.00 & 5.13 & 320 \\
\hline 5 & $\begin{array}{l}\text { Ineffective } \\
\text { communication }\end{array}$ & 194 & 873 & 4.50 & 2.02 & 126 & 315 & 2.50 & 1.70 & 320 \\
\hline 6 & $\begin{array}{l}\text { Inadequate training of } \\
\text { micro entrepreneurs }\end{array}$ & 210 & 945 & 4.50 & 6.92 & 110 & 230 & 2.09 & 6.32 & 320 \\
\hline 7 & Group lending barriers & 152 & 700 & 4.61 & 11.80 & 168 & 420 & 2.50 & 9.60 & 320 \\
\hline & Total & 1346 & 5918 & 30.86 & 27.96 & 894 & 2072 & 16.19 & 27.59 & 2240 \\
\hline & Aggregate mean & 192 & 845 & 4.41 & 4.00 & 128 & 296 & 2.31 & 3.94 & 320 \\
\hline
\end{tabular}

Source: Field Survey, 2013

Table 4 showed that 192 respondents, representing about 60 percent agreed that the problems of microcredit affected the performance of the microenterprises while about 40 percent (128 respondents) differed in this opinion.

Table 5: Statistical Analysis of Responses

\begin{tabular}{|c|c|c|c|c|c|c|c|c|}
\hline $\begin{array}{l}\text { Responses } \\
\text { (options) }\end{array}$ & $\begin{array}{l}\text { No. of } \\
\text { Respondents }\end{array}$ & $\begin{array}{l}\text { Mean } \\
\text { Scores } \\
\text { X }\end{array}$ & $\begin{array}{l}\text { Standard } \\
\text { deviation }\end{array}$ & $\begin{array}{l}\text { Degrees } \\
\text { of } \\
\text { freedom }\end{array}$ & $\begin{array}{ll}\mathrm{Z} & - \\
\text { calculated }\end{array}$ & $\begin{array}{l}\mathrm{Z} \\
\text { critical }\end{array}$ & $\begin{array}{l}\text { Level of } \\
\text { significance }\end{array}$ & Decision \\
\hline Agree & 192 & 4.41 & 4.00 & & & & & \\
\hline Disagree & 128 & 2.31 & 3.94 & 4 & +3.28 & \pm 1.96 & 0.05 & Rejected \\
\hline
\end{tabular}

Source: Field Survey, 2013.

From table 5, the calculated $\mathrm{Z}$ - value (+3.28) was not found in the region between -9.96 and +1.96 (ie critical values of 2) at 4 degrees of freedom and 0.05 level of significance. In applying the decision rule, the null hypothesis was rejected. The $\mathrm{P}-$ Value provided a confirmation of this decision. The likelihood of finding a Zvalue greater than +3.28 was $0.5000-0.4990=0.001$. Being a two - tailed test, the P.Value $2(0.001)=0.002$, was less than the significance level, $(\mathrm{P}<0.05)$. therefore the null hypothesis was not true. The alternate hypothesis was upheld with the conclusion that the problems of microcredit have significant effects on the performance of microenterprises in Nigeria (Lind, et al, 2005). This result validates the notion in many quarters that microenterprises are being starved of bank facilities. For example, it agrees with the statement of Gillis-Harry (2012) that banks are killing businesses. The problems of microcredit among microenterprises in Nigeria has been lingering for decades and has almost defied several remedial approaches such as the Family Economic Advancement Programme (FEAP), Rural Banking Programme, Peoples Bank idea, Community Bank Programme and the latest Microfinance Bank (MfB) programme launched in 2004. The Microfinance Bank Policy was intended to cover the majority of the poor but economically active population by the year 2020 thereby creating millions of jobs and reducing the poverty level of the nation through microenterprises. It sought to increase the share of microcredit from its initial level of 0.9 percent in 2005 to 20 percent in 2020, and also shore up the share of microcredit as a percentage of the Gross Domestic Product (GDP) from 0.2 percent in 2005 to at least 5 percent in 2020. Despite these government projections, available CBN statistics showed that at the end of December, 2004, only N8.5 billion (29.5\%) of the N28.8 billion meant for microcredit was utilized. Also about $10 \%$ of the fund meant for microcredit was not utilized due to lack of appropriate framework and confidence in the existing institutions that would have served the purpose. Most of the Community Banks and Microfinance houses have since crashed like a pack of cards 
(Akinboyo, 2007, Ugoani, 1998, 1999, 2006, 2013). At the macro level, countries like, Peru, Colombia, Philippines and others have launched microcredit initiatives with the view of encouraging the flow of microloans to microenterprises. International Organizations like the United Nations Development Programme (UNDP) has been in the forefront in advocating for microcredit to microenterprises in Nigeria. (Mboho and Inyang, 2011). In view of this statistical result and historical data there is an obvious challenge of making microcredit available to microenterprises in Nigeria, as found by this study. This problem can be overcome through other measures including the recommendations of this study.

\subsection{Scope for further Research}

Further research should focus on the quality of microcredit managers to see if it has any relationships with their output.

\subsection{Recommendations}

1. The Federal Government through the appropriate regulatory agency should define penalties for institutions and individuals not complying with credit quotas to microenterprises.

2. Bank account opening formalities should be less stringent to accommodate the interest of the rural active poor who may not have the benefit of superior education. This will make them have bank accounts and benefit from microcredit.

3. Banks should rely less on elegant paper projections by consultants before allowing credit to microenterprises. Experience has shown that not all the projections usually presented were valid. They should rather pay better attention to the competence and integrity of the micro-entrepreneurs.

4. Microenterprises should keep accounts records. This will enable banks verify their turnover for loan requests.

5. Microenterprises should avoid the key-man mentality. They should see the big picture for desired growth. They should embrace capacity building to enhance their literacy level.

6. Banks should evolve a special microcredit risk apatite mechanism to take care of micro-enterprises.

7. Collateral is good as a last resort and so should never be placed first. Banks should look at business viability as a first step. They should avoid requesting micro-entrepreneurs to provide statutory certificates of occupancy when they can also take an equitable charge over equipment, inventories, etc.

8. The Central Bank of Nigeria in collaboration with microfinance institutions should embark on campaigns to educate the rural poor on the need to patronize banks.

9. Banks should make loan requests less bureaucratic because where loan application procedures are difficult microcredit to the microentrepreneur tends to be lower.

10. Microenterprises should employ efficient management such that would enable them harness their resources reach out and join the league of growing businesses.

\section{Conclusion:}

The typical bank in Nigeria demands more than five documents to establish an applicant's identity, income, and residence thereby making it complex and impossible for many poor people who live in informal dwellings with no postal addresses to open accounts. Banks see micro-entrepreneurs as largely unorganized and risky. They feel that extending credit levels to the microenterprises would be difficult to monitor and control. This is underscored by the inability of banks to exhaust their prescribed lending quotas to microenterprises in many years. Even though many microenterprises do not keep proper accounting books that should not be the major base for not extending micro-credits. Given the fact that a common characteristic of the unbanked is less education, more education does not increase the likelihood of loan repayment and collateral does not guarantee loan repayment. Therefore the twine issues of business viability, and personal integrity of the micro-entrepreneurs should matter more for the purpose of microcredit disbursals. To create more formal jobs, micro-entrepreneurs need to grow, but credit constraints often hurt that growth. Public enlightenment can ease access to credit; by contrast, can boost revenue and employment growth, in the country. This study concluded that problems of microcredit has significant effects on microenterprises in Nigeria.

\section{References:}

[1] Adamu, B.I. (2005), Small and Medium Industries equity Investment Scheme SMEIS: Pro or antiIndustrialization Central Bank of Nigeria Bullion, Oct/Dec. 2005, Vol. 29, NO. 04.

[2] Ande, J. O. M. and Jat, R. B, (1999), Problems of Financing Small and Medium Size Businesses by Banks, First Bank of Nigeria, Bi-Annual Review, Dec. 1999, Vol. 7, No. 15.

[3] Akinboyo, O.L, (2007), Microfinance Banks: Unlocking The Potentials of Micro business activities of the Nigerian Rural Economy, Central Bank of Nigeria Bullion, Jan/March, 2007, Vol. 31, No. 1. 
[4] Abumere, S.I., Aigbokham, B.E. and Mabawonku, A.O, (2002), Building the Nigerian Private Sector Capacity: An Assessment of Problems and Policy Options, Development Policy Research Center, Research paper 38, Ibadan; Nigeria.

[5] Adebusuyi, B.S (2000), Development of Small and Medium Enterprises in Nigeria, Central bank of Nigeria, Economic and Financial Review.

[6] Ashraf, Nava, Dean Karlan, and Wesley Yin (2006) Household Decision Making and Savings Impacts, Philippines, Discussion Paper 939, Yale University New Haven, Conn.

\{7\} Banking The Poor, (1999) Washington, D. C. The World Bank.

[8] Bazobery, Eduardo (2003) Rural Financial Institutions: Savings Mobilization: An International Conference on Best Practices Washinton, D.C. June 2-4.

[9] Bruett, Till, ed (2005) Measuring Performance of Microfinance Institutions: Accelerated Microenterprise Advancement Project, Washinton, D.C.

[10] Campion, Anita, and Victoria White (1999) Institutional Metamorphosis: Transformation of Microfinance NGOs into Regulated Financial Institutions, Occasional Paper No.4, Constitutive Group to Assist the poor.

[11] Campion, Anita Elizabeth Dunn, and J. Gordon Arbueke Jr. (2002) Creating a Microfinance Bank in Peru in The Commercialization of Microfinance, ed. 175 - 95 Bloomfield, CT, Kumarian Press Inc.

[12] Central Bank of Nigeria (1994) Guidelines for Finance Companies.

[13] Charitonenko, Stephanie (2003) Commercialization of Microfinance. The Philippines, Asian Development Bank Manila, Philippines.

[14] Goleman, Bett, E. (2006), Microfinance In Northeast Thailand: Who Benefits and How Much? World Bank Development 34 (9). 1612 - 1638.

Gillis-Harry, B, (2012), Banks are killing Businesses. The Nation, Vol. 7, No. 2181. Pp. 32 - 33.

[15] Donner, Jonathan, (2003) Micro-entrepreneurs and Mobiles: An Exploration of the Uses of Mobile Phones by Small Business Owners in Rwanda. Earth Institute, Columbia University, New York.

[16] …..., (2006) The use of Mobile Phones by Micro-entrepreneurs in Kigali, Rwanda: Changes to Social and Business Networks. Information Technologies and International Development 3 (2): 3-19.

[17] Essien, S.N. and Akpan, N.!. (2007) Credit Policies and Private Sector Investment in Nigeria, Central Bank of Nigeria Bullion, Vol. 31, No. 1.

[18] Eshanokpe, J, (2012) SMEs make N70.66 from Fund. The Nation. Vol. 7, No. 2283 Pp. 52.

[19] Onasanya, B. (2012) First Bank, NASSI Sign MoU on Loan Schemes. The Nation. Vol. 7, No. 2157, pp.

12.

[20] Iganiga, B.O. (2007), An Evaluation of Microfinance Policies and Institutions in Nigeria, Union Bank Digest, Vol. 11, Nos. 1 \& 2, June 2007, Lagos.

[21] Jerome, A. (1999), Unleashing The Private Sector in Nigeria. Afribank Economic and Financial Review Vol. 1, No.1, Pp. 1-20.

[22] Ledgerwood, J. \& White, V, (2006). Transforming Microfinance Institutions Washington, D.C. The World Bank.

[23] Lind, D.A, Marshal, W.G, and Wathen, S.A (2005).Statistical Techniques in Business and Economics. $12^{\text {th }}$ Edition. New York. McGraw-Hill, Irwin.

[24] Mboho, K. S. \& Inyang, A. I. (2011). Poverty Alleviation Programmes in Nigeria: A study of the United Nations Development Programme (UNDP) Micro-credit Scheme in Uyo, LGA of Akwa Ibom State.

[25] Mohammed, S.E. (2007), Establishing A Credible Small and Medium Enterprises (SMEs) Credit Guarantee Scheme in Nigeria. Lessons from the Operations of the Agricultural Credit Guarantee Scheme (ACGS).

\{26\} Moses-Ashike, H, (2012) MfBs Set To Disburse N600bn to Small Holder Farmers. Business Day, Vol. 10 No. 218 , pp. 28, Lagos.

[27] National Board for Community Banks (1993), The Establishment of Community Banks in Nigeria. An Introduction. Abuja NBCB.

\{28\} National Universities Commission, (2011), Benchmark Minimum Academic Standards For Undergraduate Programmes in Nigerian Universities. Abuja.

[29] Naya, S. (1990), Private Sector Development and Enterprise Reformis in Growing Asian Economies. An International Center for Economic Growth Publication, ICS Press San Francisco, Califonia.

[30] Nigerian Deposit Insurance Corporation-NDIC-(2011). Microfinance Certification Programme. A Study Manual (Revised). Lagos. The CIBN Press Limited.

[31] Nzenwa, S. O. E, (2000), Microcredit and Development, Lagos, Mbeyi \& Associates Ltd. 
[32] Olayiwola, and Busari D.T. (2001). Economic Reform Programme and Private Sector Development in Nigeria. Development Policy Center Research Report No. 35, Ibadan, Nigeria.

[33] Pinto, B.M, Belka, and Krajewski (1993), Transforming State Enterprises in Poland. Evidence on Adjustment by Manufacturing Firms. Brookings Papers, Eco. Act. Pp. 213 - 261.

[34] Ugoani J.N.N (1999): Evolution and Operation of the Family Economic Advancement Programme (FEAP). A Technical Report. The Prospective Accountant, Akanu Ibiam. Federal Polytechnic, Afilkpo 3rd Edition, Vol. 03, No. 3, No. 190,'Nigeria.

[35] .........., (2013) Effect of Emotional Intelligence on Bank Success Germany. Lambert Academic Publishing

[36] .........., J.N.N. (2006) Manpower Challenges in the Banking Sector. A Nigerian Perspective Managing Business in Nigeria Journal, Vol. 5. No. 03, Owerri, Motivators Consult.

[37] ............, J. N. N. (1998) Minimizing Distress in the Nigerian Banking System. The Prospective Accountant. Akanu Ibiam Federal Polytechnic Unwana, Afikpo Vol. 02, No. 190, Nigeria.

[38] Webster, L, (1999): SMEs in Vietna - On the Road to Prosperity, Private Sector Discussions MPDF, Hanoi. 